\title{
WEIGHT LOSS IN THE FIRST MONTH POST-GASTROPLASTY FOLLOWING DIET PROGRESSION WITH INTRODUCTION OF SOLID FOOD THREE WEEKS AFTER SURGERY
}

\author{
Perda de peso no primeiro mês pós-gastroplastia seguindo evolução de dieta com introdução de alimentos sólidos a partir da terceira semana
}

\author{
Camila Garcia da Costa ANDRADE, Amanda LOBO
}

From a private health clinic in São Sebastião do Paraíso, MG, Brazil.

HEADINGS - Bariatric surgery. Weight loss. Diet.

\section{Correspondence:}

Camila Garcia da Costa Andrade

e-mail: nutricionistacamila@hotmail.com

Financial source: none

Conflicts of interest: none

Received for publication: 11/03/2014 Accepted for publication: 24/06/2014

DESCRTORES - Cirurgia bariátrica. Perda de peso. Dieta.
ABSTRACT - Background: Bariatric surgery is an effective tool in treating severe obesity. It provides significant weight loss in morbidly obese people accompanied by improvement in comorbidities and quality of life. Aim: To investigate the weight loss outcomes in the first month after bariatric surgery after introduction of solids three weeks postoperatively. Methods: Thirty-two charts of patients who underwent bariatric surgery were analyzed at a private nutritional clinic in São Sebastião do Paraíso, MG, Brazil; 93,75\% of the subjects underwent Roux-en-Y gastric bypass, and 6,25\% vertical gastrectomy. The subjects were 16 to 60 years. A body mass index of 30 to $69 \mathrm{Kg} / \mathrm{m}^{2}$ was obtained. Patients were instructed to eat small amounts several times a day, eat slowly, chew foods thoroughly, substitute sugar for sweetener, stop drinking gassy beverages, set the utensils down in between meals, drink only in between meals, avoid processed condiments and fried and greasy foods. Results: In the first month after surgery, the mean weight loss was $9,7 \%$ and the percentage of excess weight loss was $23,9 \%$. It was found that there was significant statistical difference in relation to initial and final weight $(p=0,00 ; p<0,05)$. Conclusion: This protocol provides more freedom of choice in health care once one does not have to go on food intake modifications for more than three weeks; more nutritional guidelines is followed and prospective weight loss is presented.
RESUMO - Racional: A cirurgia bariátrica é ferramenta eficaz no tratamento da obesidade grave. Ela tem proporcionado perdas ponderais importantes em indivíduos com obesidade mórbida, com consequente melhora das comorbidades e da qualidade de vida. Objetivo: Verificar a perda de peso no primeiro mês após a cirurgia bariátrica com a introdução de alimentos sólidos a partir da terceira semana do pós-operatório. Métodos: No consultório próprio de nutrição em São Sebastião do Paraíso, MG, foram estudados os prontuários de 32 pacientes que se submeteram à cirurgia bariátrica, sendo que $93,75 \%$ submeteram-se ao bypass gastrointestinal em $\mathrm{Y}$-de-Roux e 6,25\% à gastrectomia vertical. Os pacientes apresentavam variação do índice de massa corporal de 30 a $69 \mathrm{Kg} / \mathrm{m}^{2}$ e variação de 16 a 60 anos de idade. O paciente passava por três consultas de aproximadamente uma hora no pré-operatório para correção de hábitos alimentares inadequados, esclarecimento de dúvidas e mudança de comportamento antes da operação. Era orientado a fracionar as refeições, comer devagar, mastigar exaustivamente os alimentos, substituir o açúcar por adoçante, cortar do cardápio bebidas gasosas e bebidas alcoólicas, descansar os talheres após cada garfada, diminuir aos poucos a quantidade de comida que ingere, não beber líquidos durante as refeições, evitar temperos industrializados, evitar preparações gordurosas e frituras. Resultados: Foi observada média na redução do peso corporal no primeiro mês após a operação de 9,7\% e observou-se média de perda de excesso de peso de $23,9 \%$ no primeiro mês. Houve diferença estatisticamente significativa comparando o peso inicial em relação ao final $(p=0,00 ; p<0,05)$. Conclusão: Este protocolo oferece mais liberdade de escolhas saudáveis uma vez que ele não precisa fazer dieta com consistência modificada por período superior a três semanas; aumenta a adesão às orientações nutricionais e resulta em perda de peso de acordo com o esperado.

$\mathrm{O}$ besity is a chronic multifactorial disease and its treatment may involve nutritional, pharmacological approaches and/or regular physical activity. However, those treatments and behavioral modifications have not ensured success ( $98 \%$ remission) for those with morbid obesity (BMI $\left.\geq 40 \mathrm{~kg} / \mathrm{m}^{2}\right)$. Facing that, bariatric surgery has been the predominant operation used to treat patients with $B M I \geq 40 \mathrm{~kg} / \mathrm{m}^{2}$ (class III obesity) or between 35 and $39,99 \mathrm{~kg} / \mathrm{m}^{2}$ (class II obesity) in the presence of comorbidities and $30-34,99 \mathrm{~kg} / \mathrm{m}^{2}$ (class I obesity) in the presence of serious-related comorbidities listed by an expert. Bariatric surgery has an effect on sustained weight loss as well as mechanic and physiological changes ${ }^{14}$.

The benefits are resolution or improvement of serious diseases such as hypertension, diabetes and hyperlipidemia ${ }^{3}$. Significant reduction happened due to a commitment to lifestyle changes, hypocaloric diet and physical activity. In treating the morbidly obese patient, bariatric surgery has a favorable impact on comorbidities improvements and quality of life ${ }^{9}$.

The Fobi-Capella procedure is the most one used to treat obesity due to its 
efficiency and lower mortality rates ${ }^{7}$.

The Swedish Obese Subjects examined the effects of bariatric surgery on 4.047 obese patients for 10 years. Two thousand and ten subjects underwent bariatric surgery and 2.037 were conventionally treated (control group). Mortality rates all-cause reasons were lower in the surgical group. In spite of being nonrandomized, this experiment showed an important evidence concerning safety and benefits of bariatric surgery ${ }^{16}$. The long-term success will depend on a bariatric surgical multidisciplinary team to help a patient change eating habits by grabbing the chances that naturally happen because of the operation ${ }^{15}$.

During preoperative care the subject must get detailed dietary guideline about the post-operative stages containing foods that cause intolerances after surgery, nutritious recipes, a simple menu focusing on the amount of protein intake and multivitamin and mineral supplements.

There are many stages after surgery. Initially, the postoperative patient's diet is limited to sugar-free clear liquids. It is consisted of water, tea, sugar-free gelatin, coconut water, and protein liquid supplement. This stage lasts 24 to 48 hours. After it the full liquid diet starts and food intake should be liquified and strained. Food should be sugar-free and the focus is on protein supplements. This stage has substantial weight loss, and nonfat milk, sugar-free, nonfat yogurt, soy beverages, protein supplements and strained fruit juice are suggested. After full liquid diet, pureed diet should be introduced according to patient's tolerance ${ }^{15}$. The aim of this stage is to practice chew and meal time. Soft diet stage, which is next, consists of smooth consistency foods to be thin enough to pass through gastric pouch ${ }^{15}$.

Diet progression is accomplished by the majority of the American Society for Metabolic and Bariatric Surgery members. Ninety-five percent of them recommend following a clear liquid diet on stage one, 94\% a liquid diet during stage two, $77 \%$ a pureed/blended diet after liquid diet, and $67 \%$ recommend soft diet before regular diet with fiber and sugar restriction (87\%).

The aim of this study was to verify weight loss in the first month after surgery in subjects undergone bariatric surgery that followed a different nutritional progression protocol having solid three weeks after surgery.

\section{METHOD}

At a private nutritional care clinic in São Sebastião do Paraíso, MG, 32 charts of patients who underwent bariatric surgery between October 2011 and September 2013 were evaluated, being 93,75\% through Roux-en-Y gastric bypass and $6,25 \%$ vertical gastrectomy. The mean age was 39,2 years and $81,25 \%$ of the subjects were women.

TABLE 1 - Main characteristics of the sample

\begin{tabular}{|l|c|c|c|c|}
\hline \multicolumn{1}{|c|}{ Variable } & Mean & SD & Minimum & Maximum \\
\hline Age & 39,2 & $\pm 12,3$ & 16 & 60 \\
\hline Height & 1,70 & $\pm 0,10$ & 1,51 & 1,86 \\
\hline Initial weight & 127,8 & $\pm 22,7$ & 88,05 & 163,95 \\
\hline Actual weight & 114,9 & $\pm 20,5$ & 78,90 & 147,05 \\
\hline Weight variation & 12,9 & $\pm 2,9$ & 6,45 & 19,75 \\
\hline \% loss & 10,1 & $\pm 1,4$ & 7,30 & 13,70 \\
\hline Initial BMI & 46,7 & $\pm 8,4$ & 31,00 & 69,70 \\
\hline Final BMI & 42,0 & $\pm 7,7$ & 27,60 & 63,50 \\
\hline Ideal BMI 25 & 68,8 & $\pm 7,2$ & 57,00 & 86,00 \\
\hline \% Excess weight loss & 23,9 & $\pm 8,2$ & 13,85 & 56,28 \\
\hline
\end{tabular}

During pre-operative phase a detailed nutritional evaluation was done in order to collect information on lifestyle, eating habits, obesity-related diseases, medications being taken, weight history, past diet review, biochemical tests, abdominal ultrasound scan, upper endoscopy and bioimpedance.

BMI was also calculated to ensure the necessity of undergoing bariatric surgery according to the Brazilian Society for Metabolic and Bariatric surgery.

Three pre-operative consultations lasted about one hour each. Topics covered unhealthy eating habits, questions, and behavioral change prior to surgery.

Patients were instructed to eat small amounts several times a day, eat slowly, chew foods thoroughly, substitute sugar for sweetener, stop drinking gassy beverages, set the utensils down in between meals, drink only in between meals, avoid processed condiments and fried and greasy foods.

The patient's family participated in the process in order to help the patient follow the post-operative guideline. Only after a nutritional evaluation one could assert whether the surgery was recommended or not. While in the hospital the diet was supervised by its own nutritionist because the patient would be discharged within 24 hours.

Diet progression was followed during post-operative stage and solids were introduced after three weeks if there was not any kind of complication, even vomiting.

The subject would receive an eight-meal full liquid diet in week 1 (Table 2).

TABLE 2 - Sample meal plan for full liquid diet

\begin{tabular}{|c|c|c|}
\hline Time & Food & Servings \\
\hline \multirow{3}{*}{$8 \mathrm{AM}$} & Skim milk or soy milk & $150 \mathrm{~mL}$ \\
\hline & Apple or pear (chopped) & 1 tablespoon \\
\hline & Whey protein or caseinate & 1 tablespoon \\
\hline $10 \mathrm{AM}$ & $\begin{array}{l}\text { Non-acidic fruit juice (strained) or } \\
\text { coconut water }\end{array}$ & $120 \mathrm{~mL}$ \\
\hline $12 \mathrm{PM}$ & Broths ( meat, fish or chicken) & $200 \mathrm{~mL}$ \\
\hline \multirow{2}{*}{$2 \mathrm{PM}$} & Orange juice & $120 \mathrm{~mL}$ \\
\hline & Carrots (chopped) & 2 tablespoons \\
\hline \multirow{3}{*}{4 PM } & Skim milk or soy milk & $150 \mathrm{~mL}$ \\
\hline & Banana & $1 / 2$ banana \\
\hline & Whey protein or caseinate & 1 tablespoon \\
\hline $6 \mathrm{PM}$ & Broths ( meat, fish or chicken) & $200 \mathrm{~mL}$ \\
\hline $8 \mathrm{PM}$ & $\begin{array}{l}\text { Non-acidic fruit juice (strained) or } \\
\text { coconut water }\end{array}$ & $120 \mathrm{~mL}$ \\
\hline \multirow{2}{*}{10 PM } & Skim milk or soy milk & $150 \mathrm{~mL}$ \\
\hline & Whey protein or caseinate & 1 tablespoon \\
\hline
\end{tabular}

Broths intake should not exceed $200 \mathrm{ml}$ (lunch and dinner) although the body's tolerance was very individual, and the patient was instructed to eat only the necessary without vomiting. Fluid intake should reach $30 \mathrm{ml}$ every five or 10 minutes by sipping slowly. At home, the subject would start protein powder and polivitamin fluids on day 1. A pill would substitute them after three weeks because it is more tolerated. The soup consistency was creamier in week 2, and some fruits such as pureed apples and pears, mashed bananas and papaya were added to stimulate chew. Those fruits were eating at juice time. In week 3 if the patient had neither nausea nor vomiting complaints, besides fruits, solids were introduced (Table 3 ). 
TABLE 3 - Sample meal plan for blended/pureed diet

\begin{tabular}{|c|c|c|}
\hline Time & Food & Servings \\
\hline \multirow[t]{2}{*}{$8 \mathrm{AM}$} & $\begin{array}{l}\text { Skim milk blended with } 11 / 2 \\
\text { tablespoon whey protein or caseinate }\end{array}$ & $150 \mathrm{Ml}$ \\
\hline & Light cracker & 1 unit \\
\hline $10 \mathrm{AM}$ & $\begin{array}{l}\text { Non-acidic fruit juice (strained) or } \\
\text { coconut water }\end{array}$ & $\begin{array}{l}1 \text { small fruit or } 1 \\
\text { large slice } 150 \mathrm{Ml}\end{array}$ \\
\hline \multirow{4}{*}{$12 \mathrm{PM}$} & Ground meat & 2 tablespoons \\
\hline & $\begin{array}{l}\text { Vegetables without skins (well cooked } \\
\text { only) }\end{array}$ & 1 tablespoon \\
\hline & Broth (beans) & 1 tablespoon \\
\hline & $\begin{array}{l}\text { Mashed potatoes, noodles or pureed } \\
\text { "polenta" (corn meal) }\end{array}$ & 1 tablespoon \\
\hline $2 \mathrm{PM}$ & Fruit & $\begin{array}{l}1 \text { small fruit or } 1 \\
\text { large slice } 150 \mathrm{~mL}\end{array}$ \\
\hline \multirow{2}{*}{$4 \mathrm{PM}$} & Skim milk & $150 \mathrm{~mL}$ \\
\hline & Whey protein or caseinate & $11 / 2$ tablespoon \\
\hline $6 \mathrm{PM}$ & Same as lunch & Same as lunch \\
\hline $8 \mathrm{PM}$ & Sugar-free gelatin & $100 \mathrm{~mL}$ \\
\hline 10 PM & Light yogurt & 1 unit \\
\hline
\end{tabular}

The patient was instructed not to force eating after being full, and protein intake should be top priority. There was a gradual introduction of other foods such as raw vegetables, more variety of fruits and vegetables the following weeks, thus the patient could have a more independent diet.

Statistical analysis used Wilcoxon T test and Pearson's chi-squared test $(p=0,00, p<0,05)$.

\section{RESULTS}

This study has indicated a mean of $9,7 \%$ weight loss in the first month after surgery. With regard to initial and actual weight of subjects, the initial weight was $127,8 \pm 22,7 \mathrm{Kg} /$ $\mathrm{m}^{2}$ and the actual weight was $114,9 \mathrm{Kg} / \mathrm{m}^{2} \pm 20,5$. The mean weight loss was $12,9 \mathrm{Kg} / \mathrm{m}^{2} \pm 2,90$. There was no significant statistical difference comparing the initial weight with the final one $(p=0,00 ; p<0,05)$ (Figure 1$)$.

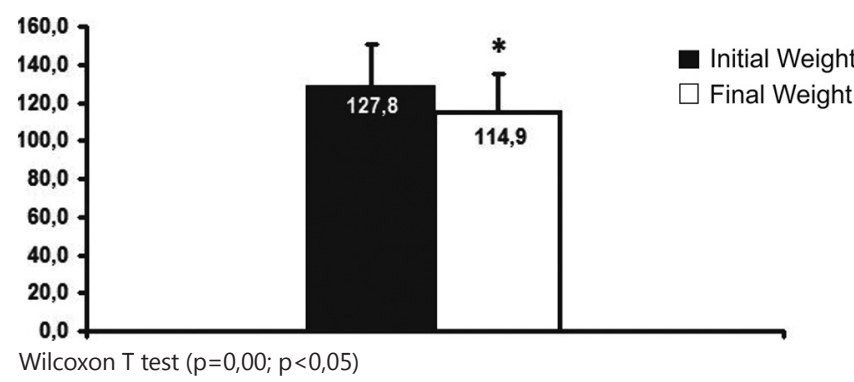

FIGURE 1 - Comparison of initial vs final weight

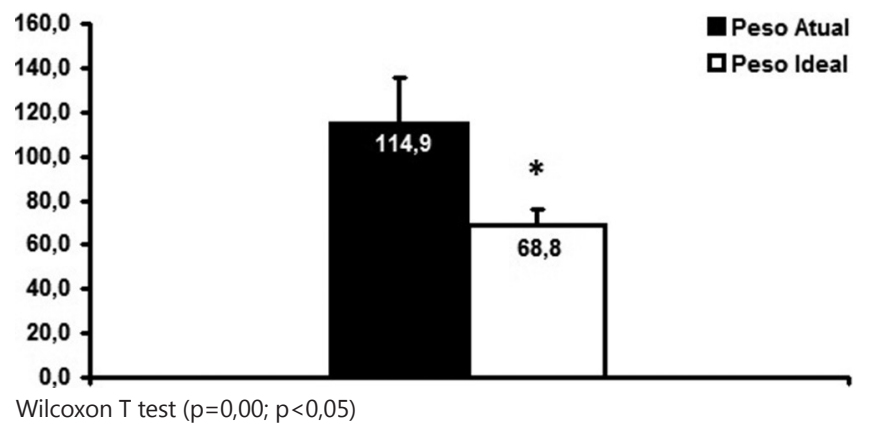

FIGURE 2 - Comparison of actual vs ideal weight
The actual and ideal weight (BMI of $25 \mathrm{Kg} / \mathrm{m}^{2}$ ) would be $68,8 \mathrm{Kg} / \mathrm{m}^{2} \pm 7,2$, being necessary a mean decrease of $46,14 \mathrm{Kg} / \mathrm{m}^{2} \pm 19,41$. There was significant statistical difference comparing the actual weight with the ideal weight ( $p=0,00 ; p<0,05)$ (Figure 2).

In relation to BMI classification prior surgery, 28 subjects $(87,5 \%)$ were classified as obese class III, three $(9,40 \%)$ class II and only one $(3,10 \%)$ class I. After surgery, one $(3,10 \%)$ was classified overweight, three $(9,40 \%)$ class I, $12(37,5 \%)$ class II and 16 (50,0\%) class III.

In relation to BMI classification, data showed that in the pre- and post-operative period, three subjects previously classified as obese class II were classified as class I after surgery. Of 28 subjects classified as class III before surgery, 12 were class II after surgery and 16 were still obese class III. One subject classified as class I was classified overweight in the post-operative period. There was significant statistical difference $(p=0,00 ; p<0,05)$ (Table 4).

\section{TABLE 4 - Classification of inicial vs final BMI}

\begin{tabular}{|c|c|c|c|c|c|c|}
\hline \multirow{2}{*}{\multicolumn{3}{|c|}{$\begin{array}{l}\text { Classification of inicial vs } \\
\text { final BMI }\end{array}$}} & \multicolumn{3}{|c|}{ Initial BMI classification } & \multirow[b]{2}{*}{ Total } \\
\hline & & & $\begin{array}{l}\text { Obese } \\
\text { class I }\end{array}$ & $\begin{array}{l}\text { Obese } \\
\text { class II }\end{array}$ & $\begin{array}{l}\text { Obese } \\
\text { class III }\end{array}$ & \\
\hline \multirow{8}{*}{$\begin{array}{l}\text { Final BMI } \\
\text { classification }\end{array}$} & \multirow{2}{*}{$\begin{array}{l}\text { Obese } \\
\text { class I }\end{array}$} & $\mathrm{N}$ & 0 & 3 & 0 & 3 \\
\hline & & $\%$ & $0,00 \%$ & $100,0 \%$ & $0,00 \%$ & $9,4 \%$ \\
\hline & \multirow{2}{*}{$\begin{array}{l}\text { Obese } \\
\text { class II }\end{array}$} & $\mathrm{N}$ & 0 & 0 & 12 & 12 \\
\hline & & $\%$ & $0,00 \%$ & $0,00 \%$ & $42,9 \%$ & $37,5 \%$ \\
\hline & \multirow{2}{*}{$\begin{array}{l}\text { Obese } \\
\text { class III }\end{array}$} & $\mathrm{N}$ & 0 & 0 & 16 & 16 \\
\hline & & $\%$ & $0,00 \%$ & $0,00 \%$ & $57,1 \%$ & $50,0 \%$ \\
\hline & \multirow{2}{*}{ Overweight } & $\mathrm{N}$ & 1 & 0 & 0 & 1 \\
\hline & & $\%$ & $100,0 \%$ & $0,00 \%$ & $0,00 \%$ & $3,1 \%$ \\
\hline \multirow[t]{2}{*}{ Total } & & $\mathrm{N}$ & 1 & 3 & 28 & 32 \\
\hline & & $\%$ & $100,0 \%$ & $100,0 \%$ & $100,0 \%$ & 00,0 \\
\hline
\end{tabular}

Pearson's chi-squared test $(p=0,00, p<0,05)$

\section{DISCUSSION}

According to the World Health Organization the rise of obesity incidence has been happening to both men and women regardless of social classes or culture. However, obesity prevalence was higher among women as found in this study ${ }^{13}$.

Here was demonstrated a weight loss equivalent to the surgical literature found after the first post-operative month: $11,1 \%$ by Ramos et al ${ }^{12}, 10,9 \%$ by Alamo et $\mathrm{al}^{1}$, $7,96 \%$ by Nassif et al ${ }^{11}, 8,6 \%$ by Arazaki et al. ${ }^{2}, 10,8 \%$ according to Lima et al. ${ }^{10}$ and $9,1 \%$ by Garrido Júnior et al. ${ }^{8}$.

Faria et $\mathrm{al}^{6}$, considered to be a surgical success, an excess weight loss of $20 \%$ one month after surgery. That study showed a mean excess weight loss of $23,9 \%$ in the first month.

BMI is an important clinical condition predictor of patients at ambulatory follow-up visits. Ramos et al. ${ }^{12}$ reported how improved the BMI of his 30 patients was with the surgical treatment. The mean pre-operative index was $48,4 \mathrm{~kg} / \mathrm{m}^{2}$ and decreased to $43 \mathrm{~kg} / \mathrm{m}^{2}$ within one month with a reduction of nearly $11,2 \%$. Alamo et al. ${ }^{1}$ also had 30-follow-up patients to measure their BMI improvements. The mean of pre-operative BMI was $41,2 \mathrm{~kg} / \mathrm{m}^{2}$ and decreased to $36,6 \mathrm{~kg} / \mathrm{m}^{2}$, one month after surgery with a reduction of nearly $11,2 \%$. Carvalho et $\mathrm{al}^{4}$, in a comparable study had a mean BMI of $49 \mathrm{~kg} / \mathrm{m}^{2}$ prior surgery and 43,5 $\mathrm{kg} / \mathrm{m}^{2}$ after surgery (there was a reduction of $11,3 \%$ ). In that study the BMI declined from $46,3 \mathrm{~kg} / \mathrm{m}^{2}$ to $41,9 \mathrm{~kg} / \mathrm{m}^{2}$ one month after surgery. The reduction was nearly $9,5 \%$.

It is believed that nutritional guidance was essential during post-operative care. As Cruz and Marimoto ${ }^{16}$ mentioned, eating habits change like chewing all foods 
well, staying on a schedule of eating, having small meals several times a day, fruits and vegetables intake, and cutting down on foods that are high in sugar and fat was the main goal to be accomplished in the pre-operative phase. Those changes would make post-op diet intake easier and reduce the risk of complications.

The post-operative benefits are not only due to substantial weight loss resulting from caloric restriction, but also to eating habits change as well as a more active life ${ }^{9}$.

The differential treatment in the first month reduces diet monotony and provides quality of life, but it is still the first step. Surgical success will depend on food choices and behavioral changes. The patient was guided to choose healthy foods (low fat/low sugar), and also to practice physical exercises in order to maintain and gain fat free mass.

Surgery alone will not ensure ongoing success in treating obesity. Nutritional care should be for life.

It is necessary that one keeps all of the follow-up nutritional appointments after gastroplasty to cure possible undesirable symptoms and complications (vomiting, food intolerance, dumping syndrome and inadequate weight loss) to diagnose the necessity of special supplementation and discuss food intake modifications according to individual tolerance ${ }^{14}$.

It was found in this study that pre-op consultations were fundamental to change eating and behavioral habits before surgery, and a follow-up of a month was of great importance to clarify doubts and to gradually re-introduce foods in accordance with individual tolerance reaching the goal of solids introduction in week three without increasing weight loss complications compared to conventional weight loss diets.

\section{CONCLUSION}

This nutritional diet progression protocol, which encourages food intake and more freedom of healthy choices, prevents liquid and pureed diets from being monotonous because one does not have to follow it for more than a threeweek period. It makes nutritional guidance more appreciable and provides expected weight loss.

\section{REFERENCES}

1. Alamo MA, TorresCS, PerezLZ. Vertical Isolated Gastroplasty with Gastroenteral Bypass: Preliminary Results. Obesity Surgery 2006; 16: 353-358.

2. Arasaki $\mathrm{CH}$, et al. Cirurgia de obesidade mórbida pela técnica de Capella via aberta: resultados em 100 pacientes. Bol Cirur Obes 2001; 2(4):3

3. Bordalo LA, Teixeira TFS, Bressan J, Mourão DM. Cirurgia Bariátrica: como e porque suplementar. Rev Assoc Med Bras 2011; 57 (1):113-120.

4. Carvalho PS, Moreira CLCB, Barelli MC, Oliveira FH, Guzzo MF, Miguel GPS. Cirurgia bariátrica cura Síndrome Metabólica? Arq Bras Endocrinol Metab 2007 Fev; 51(1).

5. Cruz MRR, Marimoto, IMI. Intervenção nutricional no tratamento cirúrgico da obesidade mórbida: resultados de um protocolo diferenciado. Rev. Nutr. vol.17 no.2 Campinas Apr./June 2004.

6. Faria SL, Kelly EO, Faria OP. Acompanhamento nutricional póscirurgia bariátrica. Nutrição em Pauta. 2008;91:13-16.

7. Francisco MC, Barella SM, Abud TG, Vilar VS, Reibscheid S, Arasaki $\mathrm{CH}$. Análise radiológica das alterações gastrintestinais após cirurgia de Fobi-Capella. Radiol Bras 2007; 40(4): 235-238.

8. Garrido Jr AB, Halpern A, Rodrigues JJG. Cirurgia para obesidade grave: vivência de duas décadas. Rev Bras Nutr Clín 2000; 15(3):400-5.

9. Junior FCM, Junior WSS, Filho NS, Ferreira PAM, Araujo GF, Mandarino, NR, Barbosa JB, Lages JS, Lima JRO, Monteiro CC. Efeito da perda ponderal induzida pela cirurgia bariátrica sobre a prevalência de síndrome metabólica. Arq. Bras. Cardiol. vol.92 no.6 São Paulo Jun 2009.

10. Lima S, Castro B, Pacheco MG, Laurino RM, Buchmann AACM, Toschi AP. Tratamento cirúrgico da obesidade mórbida: resultados em um hospital comunitário. Bol Cirur Obes 2002; 3(3):33.

11. Nassif PAN, Lopes AD, Lopes GL, Martins PR, Pedri, LE, Varaschim $M$, Bopp, DS. Alterações nos parâmetros pré e pós-operatórios de pacientes com síndrome metabólica, submetidos a Bypass gastrointestinal em $Y$ de Roux. $A B C D$, arq. bras. cir. dig. vol.22 no.3 São Paulo JulySept. 2009.

12. Ramos APP, Abreu MRA, Vendramini RC, Brunetti IL, Pepato MT. Decrease in Circulating Glucose, Insulin and Leptin Levels and Improvement in Insulin Resistance at 1 and 3 months after Gastric Bypass. Obesity Surgery 2006; 16: 1359-1364.

13. Rangel LOB, Faria VSP, Magalhães EA, Araújo ACT, Bastos EMRD. Perfil de saúde e nutricional de pacientes portadores de obesidade mórbida candidatos à cirurgia bariátrica. Rev Bras Nutr Clin. 2007; 22(3):214-9.

14. Rocha QS, Mendonça SS, Fortes RC. Perda Ponderal após Gastroplastia em Y de Roux e Importância do Acompanhamento Nutricional - Uma Revisão de Literatura. Com. Ciências Saúde. 2011; 22(1):61-7. 